\title{
Krátký úvod do anglofonní (vědecko) fantastické poezie
}

(1)

Pavla Veselá

\begin{abstract}
A Short Introduction to Anglophone Science-Fiction and Fantastic Poetry

The following article is designed as an introduction to Anglophone science-fiction and fantastic poetry, particularly poetry featured over the past few decades in various genre anthologies and periodicals. It is neither a theoretical study nor an in-depth analysis of poetry; its objective is merely to introduce science-fiction and fantastic poetry as a phenomenon that addresses similar issues as science-fiction and fantastic prose. Notwithstanding, the article begins with a brief discussion of the definitions of science fiction and poetry. The second part focuses on poetry in science-fiction and fantastic prose; the third part then turns to science-fiction and fantastic poetry as such. After sketching its history and suggesting some places where to find such poetry, selected topics that science-fiction and fantastic poetry frequently addresses are introduced. Although occasionally older works are mentioned, the majority of the poems and criticism discussed in the article originate in the second half of the twentieth and the beginning of the twenty-first centuries.
\end{abstract}

\section{KEYWORDS}

Science-fiction and fantastic poetry; twentieth and twenty-first centuries; anglophone literature.

\section{KLÍčOVÁ SLOVA}

Vědeckofantastická a fantastická poezie; dvacáté a jednadvacáté století; anglofonní literatura.

Na první pohled se může zdát, že míchání vědecké fantastiky s poezií povede ke stejnému výsledku, jako když se hrdinové pohádky Josefa Čapka (ČAPEK 1956) pejsek a kočička rozhodnou upéct dort ze všeho, co jim chutná: mouky, 
vajíček, mléka, cukru, soli, másla, syrečku, špekových kůží, ořechů, okurek, kostí, myší, buřtů, šlehané smetany, cibule, čokolády, omáčky, česneku, pepře, sádla, bonbónů, škvarků a skořice, krupičné kaše, tvarohu, perníku a octa, kakaa a zelí, hlavy z husy a rozinek. Jak podotkla americká literární kritička Rebecca Ariel Porte, fanoušci vědecké fantastiky v básnících často vidí „křížence milovníků brokolice [a jejich] ,zkus to, bude ti to chutnat's velvyslanci vysoké kultury, kteři mají v plánu nutit své zvyky utlačovaným masám“ (PORTE 2012). ${ }^{1}$ Ani někteří básníci ovšem nebývají vůči milovníkům „pokleslého žánru“ sci-fi o moc vstřícnější. Vědeckofantastická poezie se tedy může oběma stranám jevit jako nestravitelný dort.

Nedávným příkladem tohoto př́istupu je článek amerického spisovatele a kritika Paula Cooka (známého autora a kritika vědecké fantastiky), který byl titulovaný Proč je sci-fi poezie ostudně špatná [Why Science Fiction Poetry is Embarrassingly Bad]. Autor v něm vyslovil názor, že na rozdíl od poezie básníků jako Emily Dickinson, John Ashbery a Randall Jarrell, vědeckofantastická poezie je pro ostudu, protože „nemůže být transcendentální. Nemůže být ani trochu metaforická. Nemůže být mystická. [...] Neklame, nefascinuje, nesvádí, nepřekvapuje, nedrží v napětí, neflirtuje“ (COOK 2013). Jak si ovšem povšimla F. J. Bergmann, mnohé básně Emily Dickinson - včetně jedné, kterou Cook vybral jako př́iklad „dobré“ poezie - je z určitého pohledu možné považovat za sci-fi, protože v nich lyrický subjekt cestuje časem (BERGMANN 2013).

Otázkou tedy je, jak definovat vědeckofantastickou poezii. Pokud budeme na jedné straně vycházet z klasické Campbellovské definice sci-fi jako díla určeného pro rozumné, „technicky školené, zralé muže“ (ATTEBERY 2003: 38) a na druhé straně z tradiční definice poezie podle básníků a kritiků, jako byl William Wordsworth, který poezii popsal jako „spontánní přelití silných citů“ (WORDSWORTH 1800), zůstane sci-fi poezie spíše oxymóronem. Pokud ale při definicích nebudeme vycházet $\mathrm{z}$ esenciální dichotomie rozum-emoce a nebudeme trvat na univerzálních charakteristikách (např. že sci-fi musí být o technologii a poezie o prrírodě nebo neštastné lásce), vědecká fantastika a poezie mohou mít mnoho společného.

V klasickém díle ze sedmdesátých let Metamorfózy vědecké fantastiky: o poetice a historii literárního žánru [Metamorphoses of Science Fiction: On the Poetics and History of the Literary Genre] Darko Suvin napsal, že definice sci-fi by se neměla opírat o potenciálně nekonečné pole témat, kterým se může věnovat,

1) V případě, že neuvádím informaci o překladateli, jedná se o můj překlad. 
jako je věda nebo budoucnost, ale že sci-fi je především literatura kognitivního odcizení - „literární žánr, jehož nezbytnou a dostatečnou podmínkou je přítomnost a interakce odcizení a kognice, a jehož hlavním formálním prostředkem je imaginární rámec, který je alternativou autorova empirického prostředí" (SUVIN 1979: 7-8, kurziva v originále). Jinými slovy, sci-fi se svět nesnaží pouze reflektovat. Stejně jako pohádky nebo fantastická literatura svět transformuje, vytváří jeho imaginární alternativu, ovšem na rozdíl od těchto „magických žánrů“ vychází z kognitivních zákonů. Tento bod Suvinovy definice se samozřejmě setkal s kritikou; příkladem z nedávné doby je připomínka Chiny Miévilla, že „kognitivní zákony” jsou do jisté míry otázkou ideologie, konvence a přesvědčení, a tak cestování nadsvětelnou rychlostí je ve sci-fi přijatelné, zatímco draci nejsou, navzdory tvrzení většiny fyziků, že možné není ani jedno (MIÉVILLE 2009). Jasná hranice mezi tím, co je a není nemožné, neexistuje, ale jak napsala Joanna Russ ve své eseji K estetice vědecké fantastiky, „sci-fi nesmí odporovat tomu, co víme. Domýšlet si může pouze v místech, kde nic nevíme, popř. kde jsou naše vědomosti nejisté“ (RUSS 1975). Definice vědecké fantastiky tak zůstane nadále otevřená i jiným tématům, než těm určeným „technicky školeným, zralým mužům “ - čímž ovšem neplatí, že by vše bylo př́ípustné.

Když se přesuneme do oblasti poezie, ani zde nenajdeme univerzální tematické nebo formální hranice. Dějiny jsou plné básníků, jejichž dílo bylo považováno za nepoetické, příkladem z amerického kontextu devatenáctého století je Walt Whitman, který čelil kritice, že jeho sbírka Stébla trávy [Leaves of Grass] je obscénní, nebo již zmíněná Emily Dickinson, jejíž básně byly pro publikaci formálně upraveny, aby odpovídaly dobovým konvencím. V současné době ovšem v podstatě neexistuje téma, kterému by se báseň nemohla věnovat. Definovat poezii není jednoduché ani po formální stránce: podle formalistů poezie (podobně jako sci-fi podle Suvina) způsobuje odcizení, protože je deformací „běžného jazyka,“ „lingvistickým násilím.“ Jak ale podotkl Terry Eagleton, co je to „běžný jazyk,“ který poezie údajně deformuje? „Ačkoliv ,běžný jazyk je termín, který milují oxfordští filozofové, běžný jazyk oxfordského filozofa má jen málo společného s běžným jazykem přístavního dělníka z Glasgow. [...] Myšlenka, že existuje jeden ,normální jazyk [...], je iluze“ (EAGLETON 1996: 4). Navíc ne všechny odchylky od určitých jazykových norem jsou poetické (např. slang). Vyjma toho, že délku veršů u poezie neurčuje textový editor, ale autor, poezii tedy nelze jednoduše definovat ani formálně. Když známý autor a kritik sci-fi poezie Andrew Joron (TEM 1982: xii) píše, že sci-fi poezie musí používat jazyk sci-fi způsobem, a má na mysli fragmentovaný volný verš, je jeho tvrzení obhajitelné 
pouze ve vztahu k „běžnému jazyku,“ který takový není. Zejména v současné kultuře nových médií je ovšem fragmentovaný jazyk spíše jednou z norem, tudíž fragmentovaný, volný verš čtenáře od tohoto „běžného jazyka“ a „běžného vnímání reality neodcizuje. Více odcizující vůči takovému „běžnému jazyku“ by mohl být například sonet nebo metrický epický verš. Podobně jako vědeckou fantastiku není lehké poezii definovat, i zde se zdá být nejpřívětivější otevřená definice.

Suvin, Miéville, Russ, Eagleton a Joron samozřejmě nejsou jedinými kritiky a spisovateli, kteří se definicím poezie a vědecké fantastiky věnovali. I jejich myšlenky jsou zde pouze nastíněny. Výše zmíněná debata mezi Suvinem, Miévillem a Russ například otevírá klíčový problém: na základě jakých kritérií je možné formulovat hranici mezi vědeckou fantastikou a fantastikou? Další otázka, které se zde nevěnuji, je rozdíl mezi „mytickým“ a „kritickým“ odcizením (SUVIN 2017). Mým cílem v tomto krátkém úvodu ovšem není teoretická úvaha o definicích žánrů a forem; za cíl si kladu pouze definice vědecké fantastiky a poezie otevřít natolik, aby bylo patrné, že vědeckofantastická poezie není nikterak nemožným jevem. Z praktických důvodů se po zbytek článku pokusím krátce představit vědeckofantastickou a fantastickou poezii publikovanou na dvou místech: jednak představím poezii zahrnutou ve vybrané vědeckofantastické a fantastické próze, a hlavně se budu věnovat vybrané poezii publikované v žánrových antologiích a časopisech, zejména $z$ posledních desetiletí. $Z$ následujících stránek je patrné, že poezie, která se objevuje v současných žánrových publikacích, vědeckou fantastiku a fantastiku nezřídka směšuje (často je používán i termín „spekulativní poezie“). Ani já se na těchto stránkách nepokouším jednotlivá díla systematicky žánrově třídit a ponechávám otázku jejich kategorizace spíše na pozadí. Ze studie ovšem mimo jiné vyplývá, že pokud bychom definovali vědeckou fantastiku na základě toho, co je v rámci žánru publikováno - jak navrhují například Edward James a Norman Spinrad (ROBERTS 2000: 2) - jakákoliv hranice mezi vědeckou fantastikou a fantastikou by byla v zásadě popřena.

\section{Poezie v próze}

Přesuňme se tedy ke konkrétním příkladům. První budou básně, které figurují ve vědeckofantastické a fantastické próze. Jak podotkl např́iklad Gary 
Westfahl v Greenwoodské encyklopedii fantastiky a vědecké fantastiky [The Greenwood Encyclopedia of Science Fiction and Fantasy], autoři vědecké fantastiky a fantastiky někdy používají poezii pro titulky svých děl, popř. do prózy vkládají fragmenty básní. Jako příklady Westfahl uvedl povídku Raye Bradburyho Přijdou vlahé deště [There Will Come Soft Rains], která cituje stejnojmennou bá(1) seň Sary Teasdale ( $\mathrm{k}$ této povídce se ještě vrátím), Opěvuji elektrické tělo [I Sing the Body Electric], kde je inspirací báseň Walta Whitmana; a Zlatá jablka slunce [Golden Apples of the Sun], ve které je jako titul použit verš z básně Williama Butlera Yeatse. Originální poezie je zahrnuta např́klad i v dílech Lewise Carrolla, J. R. R. Tolkiena, Johna Myerse, Hala Clementa a Roberta Heinleina (WESTFAHL 2005).

Ačkoliv Westfahl na závěr svého př́ispěvku poněkud necitlivě uvádí, že poezie ve sci-fi a fantastice přeživá a bude přeživat ,jako přijemná příležitostná odbočka," která drží poezii při životě (WESTFAHL 2005: 610), má pravdu, když tvrdí, že přítomnost poezie ve sci-fi a fantastice není nezanedbatelná. Kromě příkladů, které sám uvádí, stojí za zmínku mnoho autorů tzv. Nové vlny. Jak napsal Thomas L. Wymer, např́iklad povídka Růže pro kazatele [Rose for Ecclesiastes] Rogera Zelaznyho je protkaná „nikterak subtilními referencemi nejen k Bibli, ale i k dílům Thomase Graye, Shakespeara, Saint-Exupéryho, Danta, Blakea, Audena, Sartra a mnoha dalších" (WYMER 1999: 320). Podle Jane M. Lindskold, která se věnovala vlivu poezie na prózu Rogera Zelaznyho, Zelazny - který publikoval poezii i samostatně - byl ovlivněn mimo jiné poezií Blakea, Yeatse, Audena, Dylana Thomase a Harta Cranea (LINDSKOLD 1992). Další známý autor, tentokrát z britské strany, je Brian Aldiss, který sám sebe v roce 1969 pro jednu antologii popsal následovně: „V roce 1949 jsem přišel do Oxfordu pracovat do knihkupectví s rozhodnutím stát se básníkem. Místo toho jsem skončil jako prozaik, převážně autor sci-fi. Stále doufám, že budu básníkem" (LUCIE-SMITH 1969: 131). Aldiss je znám zejména jako autor prózy, ale publikoval i několik sbírek básní a básně se v jeho próze někdy i objevují (výrazně např. v románu z roku 1969 Naboso v hlavě [Barefoot in the Head]). Konečně například Dan Simmons je znám svými odkazy na Johna Keatse a podle T. S. Millera je jeho román „Hyperion [Hyperion] nejznámější sci-fi adaptací Canterburských povídek [The Canterbury Tales]“ (MILLER 2013: 132). (Miller mimo jiné našel ozvěny Canterburských povídek v díle mnoha autorů, včetně Joanny Russ a Margaret Atwood, a jeho výše zmíněný článek se mimo jiné věnuje básni Anthonyho Broda z roku 1956 s názvem Flying Chaucer [v překladu Létající Chaucer, ale tím se ztratí hř́ička se slovy „Chaucer“ a „saucer”].) 
Vzhledem k tomu, že poezii do své prózy zahrnulo bezpočet dalších autorů, včetně Philipa K. Dicka, Joe Haldemana, Ursuly K. Le Guin a Kima Stanley Robinsona, bylo by složité vymýšlet všeobecné závěry o její roli. Básník a kritik Steve Sneyd, ve svém článku o poezii v Aldissově již zmíněném románu Naboso $v$ hlavě, se řídil autorovým vysvětlením, že poezie $\mathrm{v}$ jeho próze otevírá kubický svět mnoha pohledů. „Tyto básně,“ napsal Aldiss, „se snaží příběh vidět v jiném světle. Nebo do něho umožní vstoupit okrajovým postavám. Takže svým způsobem změní nebo rozšírí čtenářův pohled na děj“ (SNEYD n.d. „V řadě nad srázem" [Lining Up on the Precipice]). Ačkoliv v konkrétním románu Aldisse poezii lze takto interpretovat, $\mathrm{v}$ jiných dílech může mít jinou roli. $\mathrm{V}$ dystopiích například poezie často naznačuje přesah v nich popsaných „horších světů“: v Orwellově 1984 [Nineteen Eighty-Four] poezie oživuje pamět potlačenou režimem a Huxleyho Báječný nový svět [Brave New World] zahrnuje kromě poněkud omšelých písní solidarity temnou poezii Shakespeara, která v obyvatelích této dystopie probouzí emoce režimem jinak kontrolované. $V$ již zmíněné povídce Raye Bradburyho Přijdou vlahé deště je to podobné: v post-apokalyptickém světě, který je v ní popsán, lidstvo vyhynulo. Jediné, co z civilizace zbývá, je automatizovaná technologie, která ovšem v závěru sama sebe ničí. Přežívá tak pouze okolní příroda, popsaná v básni Sary Teasdale, kterou v povídce předříkává automat již mrtvým obyvatelům planety. Je to jediná naděje (ovšem ne pro lidstvo), která v tomto dystopickém světě není zničena:

„Přijdou vlahé deště, zem se rozvoní,

vlaštovky se vrátí z kraje mandloní:

kvákání žab zazní večer z rybníků, trnka vyšňoří se v bílou tuniku;

červenky si vezmou čapky z šarlatu, a s pískotem slétnou k větvím akátů;

kdo z nich o válku se bude starati,

nebo o to, kdy se mír zas navrátí?

Nikdy nenapadne ptáka ani strom,

nezajde-li celé lidstvo v boji tom.

Samo sličné Jaro - nevěř, nechceš-li -

sotvakdy se dozví, že jsme odešli.“

(BRADBURY 1977: 221, přeložila Jarmila Emmerová) 
Do utopií, jak jsem již podrobněji popsala v jiných publikacích, poezie zase naopak často vnáší negativitu, které se dílo v próze nevěnuje. Př́kladem by zde mohl být známý román Edwarda Bellamyho Pohled do budoucího ráje [Looking Backward 2000-1887]. Ten zahrnuje úryvek z Tennysonovy básně Panské sídlo Locksley [Locksley Hall], která mimo jiné popisuje vřavu a násilí revoluce, což protiřečí popisu historických změn v utopii Bellamyho (tam jsou dějiny popsány jako klidná a mírná evoluce) (BELLAMY 2000: 98). Podobných případů, kdy poezie vnáší do utopického díla negativitu jinde v něm potlačenou, je zejména $\mathrm{z}$ období devatenáctého století a počátků století dvacátého mnoho. Například jediná báseň citovaná v novele Mary Griffith Za tři sta let [Three Hundred Years Hence] se věnuje otázce, o které, jak přiznává průvodce po této utopii, není prŕijemné mluvit: o masakru původního indiánského obyvatelstva (GRIFFITH 1836: 90). Temné a smutné stránky utopické společnosti do ní nacházejí cestu skrz poezii i v Moderní utopii [A Modern Utopia] H. G. Wellse. Jedním z básníků, kteří jsou uznáváni v této imaginární společnosti, je Wellsův skutečný současník William Ernest Henley. Báseň, jejíž fragment je v Moderní utopii citovaný, Henley napsal, když byl upoután na nemocniční lůžko poté, co přišel o nohu, a je plná obrazů temnoty, hrůzy, utrpení a snahy přežít v podmínkách bezmoci. Báseň i její autor jsou tak př́kladným protipólem obyvatelům Wellsovy utopie, kteři jsou zdraví, silní a spokojení. Poezie v Moderní utopii tak opět poukazuje na temnější stránky života než ty, které jsou popsány v próze (WELLS 1967: 226).

\section{Stručná historie (vědecko)fantastické poezie}

Přesuňme se nyní k poezii, která byla publikována samostatně. Kritické studie o vědeckofantastické a fantastické poezii často začínají zdůrazněním, jak dlouhou má tato poezie tradici. Edward Lucie-Smith v úvodu k antologii Držím tvých osm rukou: Antologie vědeckofantastické poezie [Holding Your Eight Hands: An Anthology of Science Fiction Verse] píše, že „vědeckofantastická poezie je žánr starší než samotná vědecká fantastika” (LUCIE-SMITH 1969: xiii). Jako příklad uvádí mimo jiné Homérovu Odysseu. Další kritici přidávají např́ílad rané germánské verše a norské ságy, které „kulminují v Beowulfovi, artušovských romancích a několika příbězích Chaucera, ve kterých jsou zmíněny nadpřirozené jevy" (HYLES 1989: 2). Z dob pozdějších je potom často jako příklad uvádě- 
na vybraná poezie Edmunda Spensera, Johna Donna i Johna Miltona. Někteří kritici ovšem zdůrazňují, že moderní podobu vědeckofantastické a fantastické poezie najdeme až v devatenáctém století; např. Lisa Yaszek a Patrick B. Sharp podotýkají, že „moderní spekulativní poezie se rozvinula v devatenáctém století společně s růstem gramotnosti, profesionalizací vědy a masivním rozmachem industrializace“ (YASZEK a SHARP 2016: 237). Jako příklad uvádějí vybranou poezii autorů jako Samuel Taylor Coleridge, Edgar Allan Poe, Walt Whitman, Robert Burns a George Gordon Byron.

$\mathrm{V}$ první polovině dvacátého století vědeckofantastickou a fantastickou poezii publikovali např. C. S. Lewis, W. B. Yeats a Clark Ashton Smith. Všeobecně se v této době (vědecko)fantastická poezie začala přesouvat do žánrových časopisů, na okraje „literárního“ světa. Jak podotkl R. D. Mullen, dobové žánrové časopisy jako Koráb [The Argosy], Kavalír [The Cavalier] a Dobrodružství [Adventure] zahrnovaly poezii, a poezie se objevila i v hlavních meziválečných a poválečných vědeckofantastických a fantastických publikacích, včetně Úžasných př́běhů [Amazing Stories], které založil v roce 1926 Hugo Gernsback, Šokujících př́běhů [Astounding Stories], Podivných př́běhů [Weird Tales] a Časopisu fantazie a vědecké fantastiky [The Magazine of Fantasy and Science Fiction] (MULLEN 1995). Již zmíněný Clark Ashton Smith, společně se Stantonem A. Coblentzem a Lilith Lorraine, založili básnickou skupinu zvanou Kosmičtí nebo Hvězdní básníci [Cosmic/Stellar Poets] a v roce 1951 Lorraine publikovala sbírku Víno údivu [Wine of Wonder]. Poezie byla důležitá i pro skupinu zvanou Futuriáni [The Futurians]; v roce 1938 Frederick Pohl a Cyril Kornbluth založili Spolek básníků vědecké fantastiky [The Science Fiction Poets' Guild]. V této době vzniklo i několik časopisů, které se specializovaly na (vědecko)fantastickou poezii, např. populární Hvězdné dráhy: Mezinárodní čtvrtletník vědeckofantastické poezie [Starlanes: The International Quarterly of Science Fiction Poetry].

$\mathrm{K}$ největšímu rozmachu vědeckofantastické a fantastické poezie došlo v šedesátých letech s příchodem tzv. Nové vlny a v letech sedmdesátých. Jak bylo již zmíněno, mnozí autoři v této době zahrnovali poezii do své prózy. Poezie se začala objevovat i v prestižních žánrových antologiích a bylo publikováno i několik antologií specializovaných na vědeckofantastickou a fantastickou poezii. Např́klad Hranice pohybu: Antologie vesmírné poezie [Frontier of Going: An Anthology of Space Poetry, ed. John Fairfax, 1973] se věnovala zejména poezii o vesmíru; již zmíněná antologie Držím tvých osm rukou (ed. Edward Lucie-Smith, 1968) zahrnuje (vědecko)fantastickou poezii různých témat. $\mathrm{V}$ roce 1969 byl založen časopis specializující se na vědeckofantastickou 
a fantastickou poezii Kinesis [Kinesis], dále (vědecko)fantastickou poezii otisklo i několik mainstreamových básnických časopisů. Podle Roberta Fraziera - jednoho $\mathrm{z}$ hlavních autorů, kritiků a propagátorů poezie z tohoto období - přelomová byla léta sedmdesátá, zejména roky 1977 a 1978, kdy bylo vydáno několik sbírek. V roce 1978 také Suzette Haden Elgin založila Asociaci vědeckofantastické poezie [The Science Fiction Poetry Association], která existuje doposud. Kromě oficiální publikace Hvězdná čcára [Star*Line] asociace každoročně vydává Rhyslingovu antologii [The Rhysling Anthology], která zahrnuje vybranou (vědecko)fantastickou poezii publikovanou v předchozím roce ( $\mathrm{z}$ výběru se potom udělují dvě ceny: za krátkou báseň pod 49 veršů a za báseň delší).

$\mathrm{Na}$ konci sedmdesátých let a v letech osmdesátých vzniklo několik časopisů specializujících se na vědeckofantastickou a fantastickou poezii, např. $R e$ vue spekulativní poezie [Speculative Poetry Review]. V posledních desetiletích se přidaly např. Oko k teleskopu [Eye to the Telescope], Mytické delirium [Mythic Delirium] nebo Skřítkovo ovoce [Goblin Fruit]. Časopisy jako Zvláštní obzory [Strange Horizons] pravidelně poezii zahrnují, stejně tak jako mainstreamové časopisy Vědecká fantastika Asimova [Asimov's Science Fiction], Časopis fantastiky a vědecké fantastiky [The Magazine of Fantasy and Science Fiction] a Ana$\log$ [Analog]. Od sedmdesátých let bylo publikováno i bezpočet antologií, např. Hořící vizí: Poezie vědy a fantastiky [Burning with a Vision, ed. Robert Frazier, 1984] a Poly: Nové spekulativní psaní [Poly: New Speculative Writing, ed. Lee Ballentine, 1989]. Za zmínku z posledních let stojí např. antologie Kde propalují rakety: Současná britská vědeckofantastická poezie [Where Rockets Burn Through: Contemporary Science Fiction Poems from the U.K., ed. Russell Jones, 2012] nebo sbírka z Austrálie, Hvězdy jako písek [Stars like Sand, ed. P. S. Cottier a Tim Jones, 2014). Existují i nové tematické antologie, příkladem je Moment změny: Antologie feministické spekulativní poezie [The Moment of Change: An Anthology of Feminist Speculative Poetry, ed. Rose Lemberg, 2012), která podle její editorky zahrnuje „poezii různých žánrů - mytickou, fantastickou, vědecko-fantastickou, historickou, surrealistickou, magicko-realistickou a nepopsatelnou, poezii autorů všech barev pleti, poezii autorů z USA, Kanady, Británie, Indie, Španělska a Filipín, poezii první i druhé generace imigrantů, poezii fyzicky zdatných i fyzicky postižených, hetero i homosexuálních, básníků identifikujících se jako ženy, muži, trans i osoby genderově nedefinovatelné“ (LEMBERG 2012). K nejvíce publikovaným autorům z posledních desetiletí patří Edwin Morgan, D. M. Thomas, Steve Sneyd a Andrew Darlington a američtí básníci Bruce Boston, Andrew Joron, Robert Frazier a Kathryn Rantala. Mnoho dalších, kteří publikovali 
poezii, je známo spíše díky své próze, např. již zmínění Aldiss, Le Guin, Disch a Atwood. Nová jména, která se pravidelně objevují v časopisech a antologiích z posledních let, jsou např. Mike Allen, Elizabeth Barrette, Catheryne M. Valente, Amal El-Mohtar a Bryan Thao Worra. (K některým z nich se ještě vrátím, až se budu věnovat konkrétním básním.)

V záplavě autorů a děl je těžké poezii publikovanou v žánrových časopisech a antologiích charakterizovat. Podle již zmíněné Elgin musí mít sci-fi báseň dvě části, jednou z nich je vyprávění (ELGIN 1999). Frazier, na základě poezie publikované v Rhyslingových antologiích z let 1978 až 2004, uzavřel, že většina této poezie skutečně nějaký příběh vypráví (FRAZIER 2005: 20). To je ovšem poznatek učiněný z velmi malého zlomku. Například Patrick $D$. Murphy, jeden z editorů kritické sbírky o vědeckofantastické a fantastické poezii Poetická Fantastika [The Poetic Fantastic], napsal, že v současné době je těžké brát vážně fantastickou metrickou romanci nebo klasický epos, i proto byly reakce na dlouhé básně C. S. Lewise nebo Fredericka Turnera vesměs negativní (MURPHY 1989: xviii). Tuto domněnku nedávno potvrdil i Sneyd, podle kterého je vědeckofantastická poezie typicky psána formou volného verše, i když výjimky (např. haiku) existují (SNEYD 2012: 24). Různorodá je vědeckofantastická a fantastická poezie i tematicky. Básně publikované ve výše zmíněných časopisech, antologiích a sbírkách se všeobecně věnují stejným tématům, kterými se zaobírá současná próza, tedy často se v nich vydáme na meziplanetární cesty nebo do prostoru ovládaného informační a jinou technologií. Neméně oblíbeným tématem je destrukce životního prostředí a různé otázky z oblasti biologie. Ačkoliv většina představuje svět neutrální nebo negativní, v podobě básně existují i utopie.

$\mathrm{V}$ poslední části tohoto stručného úvodu do (vědecko)fantastické poezie se přesunu k několika př́kladům.

\section{Od vědy po utopii}

Jak jsem již podotkla v úvodu této studie, následující výběr témat vychází ze žánrových antologií a žánrových publikací. Ty zahrnují poezii různorodou, jak vědeckofantastickou, tak fantastickou. Scott E. Green - básník, kritik, editor a autor průvodce po vědeckofantastické poezii - v jednom ze svých článků dokonce zmiňuje, že mnohé básně v žánrových publikacích jsou o životě vědců 
a o vědě samotné (GREEN 2001). Samozřejmě takovou poezii lze stěží považovat za vědeckofantastickou či fantastickou (stejně jako román o vědci či vědě není vědecká fantastika ani fantastika), ale pravdou zůstává, že mnoho básní $\mathrm{v}$ žánrových publikacích skutečně o vědě a vědcích pojednává. Zajímavější $\mathrm{v}$ tomto kontextu jsou díla, která se snaží vědecký pohled formulovat. Například v již zmíněné antologii Poly: Nové spekulativní psaní se v úvodu dočteme, že „poezie je věda, exaktní věda, něco jako astronomie“ (BALLENTINE 1989). Př́ikladem básně, která se snaží evokovat vědecký pohled, může být „kvantová poezie“ Amy Catanzano, která podle svých vlastních slov popisuje svět viděný ne skrz Newtonovu mechaniku, ale skrz mechaniku kvantovou, tedy ne jak se jeví na viditelné úrovni, ale jak se jeví na úrovni subatomické (CATANZANO 2014).

Žánrové časopisy a antologie také často zahrnují básně o vědeckofantastické a fantastické próze, jejích autorech a postavách z různých děl, od mořských příšer a upírů přes Šípkovou Růženku a Červenou Karkulku po King Konga, Godzillu a Roye Battyho z filmu Blade Runner. Např́klad již zmíněný Disch ve své sbírce poezie Spal to [Burn This] věnoval několik básní svým kolegům a kolegyním Harlanu Ellisonovi, Susan Sontagové, Robertu Blyovi, Petru Nicholsovi a mnoha dalším (DISCH 1982). Jiní se naopak nechali inspirovat dílem Dische, např. Mike Allen, který ve své básni Stoupající [Ascending] převrací Dischovu známou povídku Klesající [Descending], v níž hrdina klesá a klesá na jezdících schodech až na dno obchodního centra a na závěr s úděsem zjištuje, že schody směrem vzhưru nefungují. Allenova báseň byla publikována rok po Dischově smrti a popisuje, jak mrtvý básník vzlétá vzhůru na křídlech svých démonických slov (ALLEN 2010: 20). Co se postav ze sci-fi a fantastické prózy týče, jako příklad lze uvést báseň Osm největších koníčků upíra [Eight Vampire Hobbies] Jamese S. Dorra, kde, jak napovídá titul, je popsáno osm zálib úpírů, včetně lámání křižůu, navštěvování zubařů a rozorávání česnekových polí (DORR 2011: 79-80). Zajímavá z tohoto kontextu je také báseň Edwina Morgana Píseň lochneské příšery [The Loch Ness Monster's Song]. Tu bohužel nepřeložím (jen doufám, že v ní nejsou překlepy):

„Sssnnnwhuf ff fll?

Hnwhuff hhnnwfl hnfl hfl?

Gdroblboblhobngbl bgl gl g g g g glbgl.

Drublhaflablhaflubgafgabhaflgafl $\mathrm{fl} \mathrm{fl}-$

gm grawwwww grf grawf awfgm graw gm.

Hovoplodok-doplodovok-plovodokot-doplodokosh? 


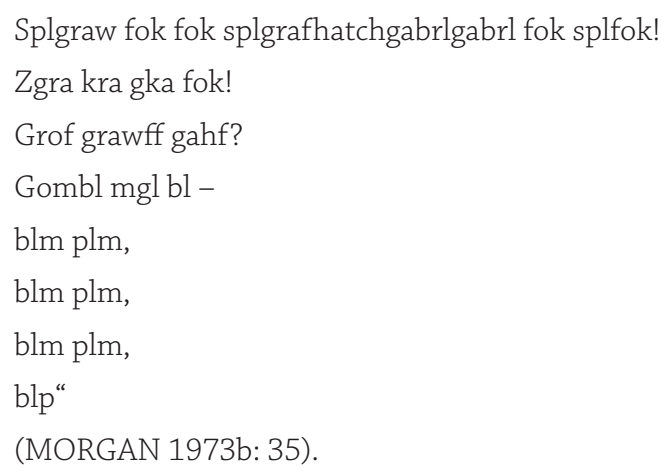

Dalším oblíbeným tématem poezie v žánrových publikacích je kosmos. Básní o vesmíru, vesmírných expedicích a mimozemštanech jsou stovky, počínaje těmi, ve kterých je expanze lidstva do vesmíru oslavována, až po básně, které zmiňují temnější stránky meziplanetárních cest, například neblahé dopady na životní prostředí na Zemi i jinde. Pro příklady z první kategorie stačí zadat do hledáčku Hubble Poetry nebo si přečíst poezii z blogu amerického astronauta Dona Pettita, který se proslavil publikací fotografií z vesmíru. I již zmíněná antologie Hranice pohybu zahrnuje podobnou poezii, vhodnou ilustrací jsou básně jejího editora Johna Fairfaxe Kolumbus nebe [Columbus of the Sky] (FAIRFAX 1973a: 51) a Procházka vesmírným prostorem [Space Walk] (FAIRFAX 1973b: 32). Další básně z této a jiných publikací ovšem upozorňují i na problematické aspekty vesmírných expedic. Například v Aldissově Vesmírném pohřbu [Space Burial] je zesnulý astronaut vypuštěn do vesmíru (ALDISS 1984: 8) a v temnější verzi D. M. Thomase Limbo [Limbo] z kosmické lodi astronauti brutálně vyhostí „ilegálního přistěhovalce“ (THOMAS 1973: 52). Častým tématem básní o cestách vesmírem je také odcizení, které kosmonaut po dlouhém pobytu mimo Zemi cítí po návratu. Skeptičtější hlasy se zaměřují i na samotnou expanzi do vesmíru. John Heath-Stubbs ve své Kosmické básni [Cosmic Poem] například zdưrazňuje, že více než polovina obyvatel planety trpí hladem a nedostává se jí základní zdravotní péče, zatímco na expanzi do vesmíru jdou miliony (HEATH-STUBBS 1973: 63). A Allen v básni Zjevný osud [Manifest Destiny] satiricky popisuje, jak lidstvo evangelizuje veškeré vesmírné obyvatelstvo a ve vesmíru buduje svá satelitní městečka, oplocené komplexy a diskontní obchody (ALLEN 2007: 17). („Zjevný osud“ se odkazuje na přesvědčení evropských kolonialistů z 19. století, že expanze po severoamerickém kontinentu je oprávněná, a naznačuje, že by se lidstvo mělo více zajímat i o to, co vesmírné expedice přinesou vesmíru, a ne pouze o zisk, který přinesou určitým lidem.) 
Vztah s př́ipadnými mimozemskými civilizacemi je někdy brán s humorem (například v básni F. J. Bergmann 100 důvodů, proč mít sex s mimozemštanem [100 Reasons to Have Sex with an Alien], která popisuje přesně, co je uvedeno v titulku (BERGMANN 2015: 49-51). Vážně o potenciálních důsledcích lidského jednání ve vesmíru pojednává např. již zmíněný Edwin Morgan (ačkoliv z jeho básně o lochneské příšeře to nemusí být patrné). Jak napsal Sneyd, jedna z básní nejčastěji zařazovaných do antologií Morgana První lidé na Merkuru [The First Men on Mercury] ze sbírky Z Glasgowa na Saturn [From Glasgow to Saturn] popisuje snahu lidí na jedné straně humanizovat a tak kontrolovat radikální diferenci a na straně druhé ostatní dehumanizovat (MORGAN 1973a: 63-64; SNEYD 2012: 23). Z Morganovy pozdější tvorby stojí za zmínku v tomto kontextu např́ílad Otázka [The Question] ze sbírky Sny a jiné noční mưry [Dreams and Other Nightmares], která popisuje pustinu způsobenou kolonizací (MORGAN 2012: 27).

Samozřejmě se objevují i díla o kolonizaci Země, příkladem je báseň Asy Benveniste Zahradníci [The Gardeners], ve které si mimozemštané z planety Země udělají zdroj obživy (BENVENISTE 1969: 5-6), častější se ale zdají být básně o mimozemštanech, kteří Zemi navštíví v dobré vůli, a bud' se vracejí znuděni jako v Prázdninách na Zemi [A Vacation on Earth] (DISCH 1984: 39), znechuceni lidským barbarstvím jako v básni Misionář [Missionary] (THOMAS 1969: 107-109), popřípadě se nevracejí vůbec. Tady bych pro ilustraci mohla místo další básně použít hudbu. Doba rozkvětu vědeckofantastické a fantastické poezie v šedesátých a sedmdesátých letech byla také dobou rozkvětu hudby inspirované (vědeckou) fantastikou. Dobrý vztah existoval mezi (vědeckou) fantastikou, jazzem a rockem. Dílo Davida Bowieho z jeho Ziggy Stardust období a film Muž, který spadl na Zemi [The Man Who Fell on Earth], ve kterém si Bowie zahrál hlavní postavu, jsou př́ikladnou ukázkou, jak bezbrannou mimozemskou civilizaci pohltí intriky a ziskuchtivost lidí.

Bowieho neštastně končící mimozemštan je i vhodným mostem $\mathrm{k}$ posledním dvěma tématům, kterým se budu krátce věnovat: dystopii a utopii. Apokalyptická a dystopická poezie je jedna z nejsilněji zastoupených v žánrových publikacích. Není vždy temná a strašidelná, je možné narazit i na básně s tituly typu Post-apokalyptický kartáček na zuby [Post-Apocalyptic Toothbrush], kde je lyrickým subjektem ubohý kartáček na zuby, který lidé prchající před apokalypsou zapomenou (LADYZHETS 2016: 34). Apokalypsa je v některých básních popsána podobně jako v básni Sary Teasdale, tedy pro ostatní obyvatele planety nic neznamenající nebo jim dokonce poskytující úlevu. Mnohé básně s apoka- 
lyptickou tematikou jsou ovšem spíš hořké a satirické; k hlavním tématům patři válka, instrumentalizace společnosti a nenávratná destrukce životního prostředí. Z dob studené války jsou např́iklad básně Mika Evanse, Všichni budeme před smrtí kosmonauty [We'll All Be Spacemen Before We Die] (EVANS 1969b: 33) a Houby [Mushrooms] (EVANS 1969a: 33). Ta první, jak je patrno z názvu, popisuje, jak si při nukleární apokalypse všichni zalétáme; $v$ té druhé přes noc jako vždy narostou houby, ovšem vzhledem k tomu, že má autor na mysli efekt atomové bomby, nikdo ty houby tentokrát nejde sbírat.

Mimo válečný kontext má technologie samozřejmě ve (vědecko)fantastické poezii i své fanoušky - technologické vynálezy jsou nejen obdivovány, ale dostávají se i ke slovu: např́iklad současný básník Rob Read vytvořil básně ze spamu, který prošel filtry do jeho mailové schránky (GALLAGHER 2013), a program Pentametron skládá básně $\mathrm{z}$ náhodně vybraných příspěvků na Twitter, které jejich autoři napsali (většinou nevědomky) v pětistopém jambickém verši. $\mathrm{Na}$ opačné straně potom stojí básně, které zdůrazňují, jak lidé novějšími a novějšími technologiemi ničí životní prostředí. Zde je pro ilustraci krátká báseň Marge Piercy Svět v roce 2000 [The World in the Year 2000]:

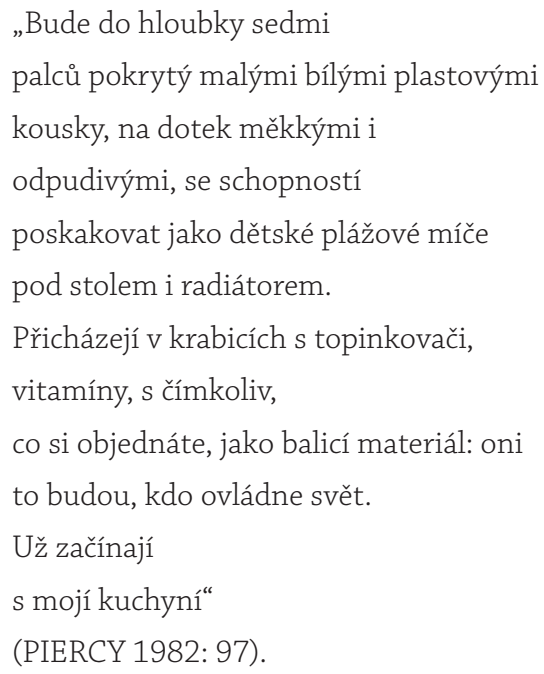

Báseň Marka Riche Sněžilo [It Snowed] zase ukazuje, jak postupnou instrumentalizací lidé přicházejí o svoje schopnosti a lidskou tvář: báseň popisuje svět, který je postupně zasypán sněhem, protože jeho obyvatelé zapomněli, že ho lze jednoduše odházet lopatou (RICH 2010: 52). 
Jakkoliv nereálná se taková vize možná jeví, pravdou je, jak píše Sneyd v úvodní eseji pro již zmíněnou antologii Kde propalují rakety, současná vědeckofantastická a fantastická poezie opakovaně „vykresluje budoucí konflikty, možné války vedené post-lidmi: zfrankensteinovatělými, geneticky upravenými, zdokonalenými, klonovanými kříženci zvířat a lidí, možná okřídlenými, jak doufali naši předci, ovšem ne pro radost z letu, ale z důvodů válečných“ (SNEYD 2012: 23). A jak se Sneyd ptá v závěru, jednou z nejpalčivějších otázek zůstává, jestli „útočné drony kontrolované z tisíce kilometrů vzdálených obrazovek, váleční roboti používající jako biopalivo nepřátelské jednotky a militarističtí zombíci a roboti“ (SNEYD 2012: 23) lidstvo k apokalypse nakonec skutečně nedovedou.

V závěru této krátké exkurze do poezie, která se v minulých několika desetiletích objevila v žánrových publikacích, se vrátím k tématu utopie. Zatím jsem se mu krátce věnovala, když jsem zmiňovala poezii v utopické próze, kde nebylo nutné pouštět se do definice. Pro následující diskuzi je ovšem nutné zmínit, že při hledání utopie v poezii vycházím z definic Lymana Towera Sargenta a Darko Suvina, které se navzdory svým rozdílům do určité míry prolínají. Oba kritiky spojuje, že popisují utopii jako společnost, komunitu, která je z pohledu autora lepší. ${ }^{2}$

I když se vědeckofantastická a fantastická poezie zdá být převážně kritická a pesimistická, utopické vize jí nejsou zcela cizí. $Z$ relativně nedávných děl je možné zmínit například Utopii [Utopia] Bernadette Mayer. Toto experimentální dílo vyšlo v roce 1984 a skládá se $\mathrm{z}$ několika typů textů, zejména z poezie (psané Mayerovou i jejími přáteli), z úryvků deníku, fragmentů př́iběhů, esejí a dopisů, parodie divadelní hry a výňatku ze Světové ročenky za rok 1984 [1984 World Almanac]. $\mathrm{V}$ úvodu básnířka mimo jiné zmiňuje, že se věnuje devíti tématům typickým pro utopie, tedy „jídlu, penězům, sexu, městu, práci, manželství, dětem, strojům, umění a literatuře“ (MAYER 1984: 15). Její utopie je globální, „neexistují žádné státy, žádné vlády. Komunity jsou tak velké, jak si jen dokážete představit, ale o všechno jídlo se lidé děli“" (MAYER 1984: 51). Svět je urbanizovaný, i když ve městech jsou farmy. V̌̌ichni mají kde bydlet, zdarma, navzájem se nevykořistují a neexistuje rasismus, sexismus a podobné formy utlačování. Ekonomika funguje bez peněz, protože peníze se staly fyzicky tak velkými, že

2) Podle Sargenta je utopie „neexistující společnost, která je detailně popsána a normálně situována v čase i prostoru. Běžně se termín používá tak, jak je zde definován, a také ve smyslu eutopie, což je neexistující společnost, která je detailně popsána, normálně situována v čase i prostoru a podle mínění autora je z pohledu jemu současného čtenáře lepší než společnost, ve které tento čtenář žije“ (SARGENT 2010: 6). Suvin definuje utopii jako „verbální konstrukci kvazi-lidské komunity, ve které jsou společensko-politické instituce, normy a individuální vztahy usporádány podle perfektnějšího principu než v komunitě autora. Tato konstrukce vzniká na základě odcizení plynoucího z alternativní historické hypotézy“" (SUVIN 1973: 132). 
člověk by potřeboval celý pokoj na to, aby v něm mohl mít pět dolarů, což vedlo k jejich zrušení. Všichni tyrani z předchozího světa - hlavy států, vysocí státní úředníci, výrobci zbraní a producenti toxického odpadu - žijí v zoologických zahradách a jsou krmeni syrovým masem, suchým chlebem a zeleninou. (Snahy je změnit např́klad pomocí psychoanalýzy bohužel vyšly naprázdno.) Neexistují téměř žádné nemoci, případně jsou nemoci léčeny především pomocí homeopatické medicíny; zubaři nejsou potřeba vůbec a lidé se nerodí ani neumírají v nemocnicích. Jak je patrno, Mayerové báseň nenabízí „koherentní kritiku společnosti ani realizovatelný politický program. Utopie není v žádném praktickém směru instruktivnî" (JACOBS 2007: 241, původní zdůraznění). I tak v ní jsou ale kromě zcela fantaskních nápadů i myšlenky realizovatelné - a hlavně je v ní patrný kritický přistup k reálnému světu, ke kterému Mayer takto navrhuje hledat alternativu.

V úplném závěru bych ale ráda zmínila, že v současnosti existuje i utopická poezie, která více staví na tradiční lyrice a pastorálních vizích. Pastorální utopické vize jsou patrné např́klad v poezii již zmíněného Suvina. Suvin je znám spíše jako kritik, ovšem publikoval i dvě sbírky poezie. V četných básních umistuje utopii spíše na horizont, ale např́klad první báseň ze série Vize z Yamady [Visions off Yamada] titulovaná Chvála úžasného pohledu [In Praise of Wonderful Sight] popisuje pastorální komunitu obklopenou přírodou (SUVIN 2010: 105-106). Obdobné vize harmonického soužití nejen lidí, ale i ostatních živých i neživých obyvatel této planety, lze nalézt i v poezii Garyho Snydera. Báseň, kterou tento stručný úvod do (vědecko)fantastické poezie ukončím, pochází právě od něho a nese název Pro děti [For the Children]:

\author{
„Zvedající se kopce, svahy \\ statistik \\ leží před námi, \\ prudký vzestup \\ všeho, nahoru, \\ nahoru, zatímco my \\ jdeme dolů. \\ Ř́ká se, \\ že v příším století \\ nebo v tom dalším, \\ jsou údolí, pastviny,
}


můžeme se tam setkat v míru

pokud se tam dostaneme.

Ke slézání těchto blížících se hřebenů

mám pro vás, vás a vaše děti

pár slov:

držte se spolu

učte se od květin

našlapujte zlehka“

(SNYDER 1974: 86).

\section{PRAMENY}

ALDISS, Brian W.

1984 "Space Burial", in Burning with a Vision: Poetry of Science and the Fantastic, ed. Robert Frazier (Philadelphia: Owlswick Press), s. 8

1969 Barefoot in the Head (London: Faber \& Faber)

ALLEN, Mike

2010 "Ascending", in The 2010 Rhysling Anthology, ed. Jaime Lee Mayer (SPFA), s. 20

2007 "Manifest Destiny", in The 2007 Rhysling Anthology, ed. Drew Morse (SPFA), s. 17

BELLAMY, Edward

2000 Looking Backward 2000-1887 (New York: Penguin Putnam)

BENVENISTE, Asa

1969 "The Gardeners", in Holding Your Eight Hands: An Anthology of Science Fiction Verse, ed. Edward LucieSmith (Garden City, NY: Doubleday), s. 5-6

\section{BERGMANN, F. J.}

2015 "100 Reasons to Have Sex with an Alien", in The 2015 Rhysling Anthology, ed. Rich Ristow (SPFA), s. $49-51$

2013 “A Broader View of Science-Fiction Poetry," Amazing Stories [online] [cit. 2018-9-04] Dostupné na internetu: <http://amazingstoriesmag.com/2013/02/a-broader-view-of-science-fiction-poetry/>

BRADBURY, Ray

1977 The Martian Chronicles (Hammersmith: Grafton)

ČAPEK, Josef

1956 Povídání o pejskovi a kočičce (Praha: SNDK) 


\section{DISCH, Thomas M.}

1984 "A Vacation on Earth", in Burning with a Vision: Poetry of Science and the Fantastic, ed. Robert Frazier (Philadelphia: Owlswick Press), s. 39

1982 Burn This (London: Hutchinson \& Co.)

DORR, James

2007 “Eight Top Vampire Hobbies," in The 2011 Rhysling Anthology, ed. David Lunde (SPFA), s. 79-80

EVANS, Mike

1969a "Mushrooms", in Holding Your Eight Hands: An Anthology of Science Fiction Verse, ed. Edward LucieSmith (Garden City, NY: Doubleday) s. 33

1969b "We'll All Be Spacemen Before We Die", in Holding Your Eight Hands: An Anthology of Science Fiction Verse, ed. Edward Lucie-Smith (Garden City, NY: Doubleday), s. 33

FAIRFAX, John

1973a "Columbus of the Sky", in Frontier of Going: An Anthology of Space Poetry, ed. John Fairfax (Herts: Granada Publishing), s. 51

1973b "Space Walk", in Frontier of Going: An Anthology of Space Poetry, ed. John Fairfax (Herts: Granada Publishing), s. 32

FRAZIER, Robert

2005 "Alchemical Post-Its: A Rhysling Primer", in The Alchemy of Stars, ed. Roger Dutcher and Mike Allen (SFPA), s. 15-21

GRIFFITH, Mary

1836 “Three Hundred Years Hence”, in Camperdown; Or, News from Our Neighbourhood (Philadelphia: Carey, Lea and Blanchard), s. 9-92

HEATH-STUBBS, John

1973 “Cosmic Poem”, in Frontier of Going: An Anthology of Space Poetry, ed. John Fairfax (Herts: Granada Publishing), s. 63

HUXLEY, Aldous

1977 Brave New World (London: Granada)

\section{LADYZHETS, Betsy}

2016 "Post-Apocalyptic Toothbrush", in The 2016 Rhysling Anthology, ed. Charles Christian (SPFA), s. 34

LEMBERG, Rose, ed.

2012 The Moment of Change: An Anthology of Feminist Speculative Poetry (Seattle: Aqueduct Press)

LUCIE-SMITH, Edward

1969 Holding Your Eight Hands: An Anthology of Science Fiction Verse (Garden City, NY: Doubleday) 
Pavla Veselá

Krátký úvod do anglofonní (vědecko) fantastické poezie

MAYER, Bernadette

1984 Utopia (New York: United Artists)

MILLER, T. S.

2013 "Flying Chaucers, Insectile Ecclesiasts, and Pilgrims Through Space and Time: The Science Fiction Chaucer," The Chaucer Review 48:2, s. 129-165

\section{MORGAN, Edwin}

1973a "The First Men on Mercury", in From Glasgow to Saturn (Cheadle: Carcanet), s. 63-64

1973b “The Loch Ness Monster's Song”, in From Glasgow to Saturn (Cheadle: Carcanet), s. 35

2012 "A Question", in Where Rockets Burn Through: Contemporary Science Fiction Poems from the U. K., ed.

Russell Jones (London: Penned in the Margins), s. 27

ORWELL, George

1983 Nineteen Eighty-Four (Harmondsworth: Penguin)

\section{PIERCY, Marge}

1982 "The World in the Year 2000", in The Umbral Anthology of Science Fiction Poetry, ed. Steve Rasnic Tem (Denver: Umbral Press), s. 97

RICH, Mark

2010 “It Snowed”, in The 2010 Rhysling Anthology, ed. Jaime Lee Mayer (SPFA), s. 52

THOMAS, D. M.

1973 "Limbo", in Frontier of Going: An Anthology of Space Poetry, ed. John Fairfax (Herts: Granada Publishing), s. 52

1969 "Missionary", in Holding Your Eight Hands: An Anthology of Science Fiction Verse, ed. Edward LucieSmith (Garden City, NY: Doubleday), s. 107-109

WELLS, Herbert George

1967 A Modern Utopia (Lincoln, NE: University of Nebraska Press)

WHITMAN, Walt

1959 Leaves of Grass, ed. Malcolm Cowley (New York: Viking)

WORDSWORTH, William

1800 Lyrical Ballads, with Other Poems (London: T. N. Longman and O. Rees) [cit. 2018-9-04] Dostupné na internetu: 〈https://www.gutenberg.org/ebooks/8905>

YASZEK, Lisa a Patrick SHARP, eds.

2016 Sisters of Tomorrow: The First Women of Science Fiction (Middletown: Wesleyan University Press) 


\section{LITERATURA}

\section{ATTEBERY, Brian}

2003 “The Magazine Era: 1926-1960," in The Cambridge Companion to Science Fiction, ed. Edward James and Farah Mendlesohn (Cambridge: Cambridge University Press), s. 32-47

BALLENTINE, Lee 1989 "Opening Salvos", in Poly: New Speculative Writing, ed. Lee Ballentine (Mountain View: Ocean View Books), číslování stránek neuvedeno

\section{CATANZANO, Amy}

2014 “Magical Correspondences, Part 2 of 6," Jacket2 [online] [cit. 2018-9-04] Dostupné na internetu: 〈http://jacket2.org/commentary/magical-correspondences-part-2-6〉

\section{COOK, Paul}

2013 "Why Science Fiction Poetry is Embarrassingly Bad," Amazing Stories [online] [cit. 2018-9-04] Dostupné na internetu: <http://amazingstoriesmag.com/2013/02/why-science-fiction-poetry-is-embarrassingly-bad/>

\section{EAGLETON, Terry}

1996 Literary Theory: An Introduction (Malden: Blackwell Publishing)

ELGIN, Suzette Haden

1999 “About Science Fiction Poetry” http://www.sfwa.org/members/Elgin/SFPoetry.htm

\section{GALLAGHER, Kristen}

2013 “WHY Spam?” Jacket2 [online] [cit. 2018-7-08] Dostupné na internetu: <http://jacket2.org/commentary/why-spam>

\section{GREEN, Scott E.}

2001 "Marketing Science Fiction Poetry," WritersWeekly [online] [cit. 2018-9-04] Dostupné na internetu: <http://writersweekly.com/this-weeks.article/marketing-science-fiction-poetry-by-scott-e-green>

\section{HYLES, Vernon}

1989 "The Poetry of the Fantastic", in The Poetic Fantastic: Studies in an Evolving Genre, ed. Patrick D. Murphy and Vernon Hyles (New York: Greenwood), s. 2-9

\section{JACOBS, Naomi}

2007 "Utopia and the Beloved Community", in Utopia Method Vision: The Use Value of Social Dreaming, ed. Tom Moylan and Raffaella Baccolini (Bern: Peter Lang), s. 223-244

\section{LINDSKOLD, Jane M.}

1992 "The Pervasive Influence of Poetry in the Works of Roger Zelazny," Extrapolation 33:1, s. 41-58 
Pavla Veselá

Krátký úvod do anglofonní (vědecko) fantastické poezie

MIÉVILLE, China

2009 "Afterword: Cognition as Ideology", in Red Planets: Marxism and Science Fiction, ed. Mark Bould and China Miéville (Middletown: Wesleyan University Press), s. 231-248

MULLEN, R. D.

1995 "From Standard Magazines to Pulps and Big Slicks: A Note on the History of US General and Fiction Magazines," Science Fiction Studies [online] [cit. 2018-7-08] Dostupné na internetu: <http://www.depauw. edu/sfs/backissues/65/mullen65.htm>

MURPHY, Patrick

1989 "Foreword", in The Poetic Fantastic: Studies in an Evolving Genre, ed. Patrick D. Murphy and Vernon Hyles (New York: Greenwood), s. xi-xxv

PORTE, Rebecca Ariel

2012 “The Best Books of Poetry for Every Kind of Science Fiction Fan” gizmondo.com [online] [cit. 2018-

9-04] Dostupné na internetu: <https://io9.gizmodo.com/5885724/the-perfect-poetry-for-every-type-ofscience-fiction-fan>

ROBERTS, Adam

2000 Science Fiction (London and New York: Routledge)

RUSS, Joanna

1975 "Towards an Aesthetics of Science Fiction," Science Fiction Studies 2:6 [online] [cit. 2018-9-04] Dostupné na internetu: <http://www.depauw.edu/sfs/backissues/6/russ6art.htm>

SARGENT, Lyman Tower

2010 Utopianism: A Very Short Introduction (Oxford: Oxford University Press)

SNEYD, Steve

2012 "Wormholing into Elsewhere", in Where Rockets Burn Through: Contemporary Science Fiction Poems from the U. K., ed. Russell Jones (London: Penned in the Margins), s. 19-24

n.d. "Lining Up on the Precipice-The Shape and Role of Poetry in Brian Aldiss' Barefoot in the Head" [online] [cit. 2018-9-04] Dostupné na internetu: <http://www.zone-sf.com/bithaldiss.html>

SNYDER, Gary

1974 "For the Children", in Turtle Island (New York: New Directions), s. 86

SUVIN, Darko

1973 "Defining the Literary Genre of Utopia: Some Historical Semantics, Some Genology, a Proposal and a Plea", Studies in the Literary Imagination 6.2, s. 121-145

1979 Metamorphoses of Science Fiction: On the Poetics and History of the Literary Genre (New Haven: Yale University Press)

2010 "Visions off Yamada", in Defined by a Hollow: Essays on Utopia, Science Fiction and Political Epistemology

(Oxford: Peter Lang), s. 105-106 
2017 “Parables and Uses of a Stumbling Stone”, Arcadia 52:2, s. 271-300

TEM, Steve Rasnic, ed.

1982 "Introduction", in The Umbral Anthology of Science Fiction Poetry (Denver: Umbral Press), s. xi-xiv

WESTFAHL, Gary, ed.

2005 The Greenwood Encyclopedia of Science Fiction and Fantasy: Themes, Works, and Wonders (Westport: Greenwood Press)

WYMER, Thomas L.

1999 “Comes Now the Power: Roger Zelazny's Transformation of Romantic Poetic Themes," Extrapolation 40:4, s. 320-324

Mgr. Pavla Veselá, Ph. D., pavla.vesela@ff.cuni.cz. Ústav anglofonnich literatur a kultur, Filozofická fakulta Univerzity Karlovy / Department of Anglophone Literatures and Cultures, Faculty of Arts, Charles University, Prague, Czech Republic; pavla.vesela@ff.cuni.cz 